\section{West's gift becomes a model}

IN a year in which 6,000 visitors passed through its doors, a new centre to bring Western environmental research and tactics to Eastern Europe is quickly becoming the focus of the region's budding environmental programmes - and their critics. Called the Regional Environmental Center (REC), the Budapestbased centre has drawn fire for, at one time or another, being too green, not green enough, too American, too Hungarian, too high-tech, and not high-tech enough. This is, says Lawrence Cohen, science and environment officer in the US embassy in Budapest, very reassuring; if everyone thinks the REC is not responsive enough to their needs, it shows, at least, that no one faction has hijacked the centre.

By most accounts the REC is thriving, as a horde of scientists, activists, government officials and companies turn to it to set up environmental surveys, grassroots non-governmental organizations, new environmental legislation and remediation campaigns.

The REC came about when the US embassy in Budapest was trying to think of something to give Hungary on the occasion of President Bush's visit in 1989. First planned as an effort to help establish environmental programmes in Hungary, its reach was extended to all of Eastern Europe as the region became democratic. Although it started with the United States alone, it is now equally supported by the European Communities (combined US and EC funding is $\$ 10$ million for 3 years) and, to a lesser extent, by Canada, Hungary, Austria, Japan, Finland, Norway and the Netherlands. Total funding is about $\$ 20$ million for 3 years.

In its first full year of operations, the centre has been deluged. It has become an important stop for visiting Western environmental researchers, as well as playing host to policy-makers, industry representatives, members of environmental and other pressure groups and students.

Most of the centre's work is now collecting and disseminating information - a quantity that has traditionally been in short supply in Eastern Europe. It is setting up a database of environmental data for the region, as well as a computer network to link the Budapest centre with small offices in several other cities in the region, where local researchers can find information and ask questions in their own language. The REC is also developing two mobile laboratories which will serve as working laboratories and classrooms to demonstrate monitoring and computer modelling equipment.

In one typical encounter last year, the REC was approached by members of

environmental groups who discovered a huge mercury contamination in eastern Hungary and asked for help. The centre invited a group of US researchers to visit and give technical advice. While the specialists were in Budapest, they prepared a report to parliament to help in developing future legislation. This year the US Peace Corps will assign 36 environmental scientists and 20 computer scientists to work through the centre in the region.

Although pollution problems in Eastern Europe are among the worst in the world, centre officials say that the state of environmental politics may be just as serious. This is partly because few in the region understand the scope of the contamination. "The realization of how great the region's environmental problems are may be greater in the West than in central Europe itself", says Branko Bosnjakovic, REC's outreach and development manager. "People here still think that they cannot afford to protest, for fear of losing their jobs."

With the prospect of better economic times, people who have lived in Eastern Europe all their lives are reluctant to slow growth with environmental measures, or to make personal sacrifices. "Now that it is possible for people to buy cars as a status symbol, they naturally want to, which means less incentive to clean up the public transportation system, and more polluting cars on the road", says Bosnjakovic.

Governments, in turn, are afraid to impose strict environmental laws, lest they discourage Western investment. And now that each nation sets its own policies, rather than taking its cues from Moscow, agreeing on environmental legislation is nearly impossible, even though most of the region's legislatures have asked the REC for advice.

Western companies contemplating investing in the region also consult the REC. They are most concerned about existing contamination, with the possibility that they might be unsuspectingly

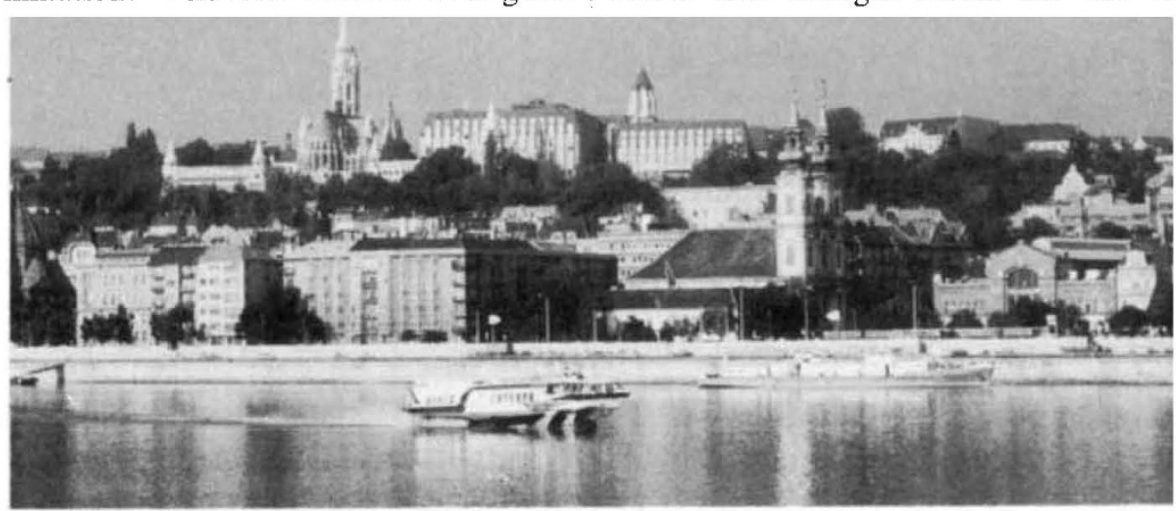

On the Danube - environmental confusion in Hungary's government.

taking over an undocumented toxic waste site the principal nightmare.

Unfortunately, the REC's attempts to set up cooperative and environmental reserach teams have been complicated by national and ethnic rivalries. "I continue to try to figure out what 'neutral' means here. What line do I toe?", wonders Stephen Wassersug, REC programme manager. At one meeting last year, representatives from non-government organizations in the two of the Yugoslavian republics refused to speak to each other. Antagonism extends to environmental officials in the new governments as well. Eastern European activists like to say that many environmental officials in their region suffer from what they derisively call "watermelon syndrome" - green on the outside but red on the inside.

Ironically, many of the political movements that brought about the rise of democracy in the region started in environmental organizations, which were among the few activist groups permitted under Communist rule. Once it became clear that the old regimes were going to fall, many of the dissidents shed their environmental cloak and campaigned openly as political candidates. This was good for the rise of democracy, of course, but it took its toll of the infant environmental movement. "After the change, people were concerned with the massive economic problems", says Bosnjakovic. "Environmental issues slipped on the political agenda." Now, 3 years later, that movement is rebuilding with people motivated by environmental rather than political concerns.

Despite the political muddle, Hungary has announced its intention to reach EC levels of environmental legislation by the mid-1990s. This is "wildly optimistic", says Cohen, "They're trying to build an entirely new environmental code at the same time that they're dealing with privatization and all the rest." The US Environmental Protection Agency has lent Hungary experts to help legislation, but most of them consider Hungary a decade away from draft EC compliance. They agree, however, that without the REC it would be even longer. 